\title{
New Petrological and Geochemical Data of the Nephelinitic Lavas and Geodynamic Implications of Mount Etinde (Cameroon)
}

\author{
Mama Ntoumbé1, Bernard Déruelle², Isaac Bertrand Gbambié Mbowou, Ismaïla Ngounouno ${ }^{3}$ \\ ${ }^{1}$ Département des Sciences de la Terre, Faculté des Sciences, The University of Ngaoundere, Ngaoundere, Cameroon \\ ${ }^{2}$ Laboratoire de Magmatologie et Géochimie Inorganique et Expérimentale (MAGIE), Institut de Physique du Globe de Paris, \\ Université Pierre et Marie Curie, Paris, France \\ ${ }^{3}$ Département de Mines Geologie, School of Geology and Mining Engineering, The University of Ngaoundéré, Meiganga, Cameroun \\ Email: ntoumbe2@hotmail.com
}

How to cite this paper: Ntoumbé, M., Déruelle, B., Mbowou, I.B.G. and Ngounouno, I. (2016) New Petrological and Geochemical Data of the Nephelinitic Lavas and Geodynamic Implications of Mount Etinde (Cameroon). International Journal of Geosciences, 7, 1452-1470. http://dx.doi.org/10.4236/ijg.2016.712101

Received: August 21, 2016

Accepted: December 27, 2016

Published: December 30, 2016

Copyright (๑) 2016 by authors and Scientific Research Publishing Inc. This work is licensed under the Creative Commons Attribution International License (CC BY 4.0).

http://creativecommons.org/licenses/by/4.0/ (c) (i) Open Access

\begin{abstract}
Mount Etinde is a Recent $(<1 \mathrm{Ma})$ strombolian-type volcano located on the southern flank of Mount Cameroon. Mount Etinde lavas are distinguished on the basis of the mineralogical compositions of their phenocrysts: olivine-pyroxene, olivine-melilite and clinopyroxene-nepheline. Some magnetite and ilmenite occur as inclusions in these early phases. Mafic mineral composition indicates that fractionation involved only limited Fe-enrichment. Oscillatory, normal and sectorial zoning in clinopyroxene relates to the differentiation and fractional crystallization of the magma. Based on the primitive mantle-normalized trace and rare earth element patterns, all nephelinites have high abundances of incompatible elements $(103<\mathrm{La}<281 ; 131<\mathrm{Ce}<$ $503)$, with negative anomalies for high field strength element $\mathrm{Ti}$ and low $\mathrm{Nb} / \mathrm{Y}(0.1-$ $0.2)$ and $\mathrm{Rb} / \mathrm{Y}(<0.03)$ ratios, suggesting derivation from a similar source. Textural characteristics and mineral chemical data, as well as whole-rock compositions, suggest that the nephelinitic lavas may have been derived from basaltic magma from a heterogeneous lithospheric mantle. Geochemical modeling of major and trace element variations indicates that the Etinde lavas could not have been produced by only fractional crystallization. Pneumatolytic reaction probably affected the pyromagmas (basaltic magma composition) and was responsible for the nephelinite rocks at lower oxygen fugacity $\left(\mathrm{fO}_{2}\right)$.
\end{abstract}

\section{Keywords}

Petrogenesis, Nephelinite, Fugacity, Geodynamic, Mount Etinde 


\section{Introduction}

Located near Batoke village (Figure 1), Mount Etinde is unique among the many volcanoes along the $1600 \mathrm{~km}$ long Cameroon Hot Line. They erupted at the very limit between the ocean and the continent, where fracturation (fractures at the continent-ocean boundary and regional N308E and N708E zones) is more intense and deeper [1]. Hyperalkaline rocks such as nephelinitic are rare, being less than $1 \%$ of all igneous rocks on the Earth [2]. Mount Etinde consists mainly of nephelinitic lavas. The lavas are characterized by a complex mineralogy and by the occurrence of rare carbonate [3]. Some nephelinites contain similar calcite in size and shape to those describe in Oldoinyo Lengai [4]. The main mafic minerals are clinopyroxene (diopside), olivine and wollastonite. Nepheline bearing rocks, present, occur in significant volume and might be of recrystallization origin. Other minerals present include characteristic magnesian spinel and perovskite. The common accessories are sphene and Fe-Ti oxides. The main products of hydrothermal alteration and/or weathering are zeolites and analcime and cancrinite. In this paper, we present new petrological, mineralogical and geochemical data (major and trace elements) on the main rock types of Mount Etinde, in order to describe the magmatic processes that led to their formation.

\subsection{Geological Framework}

The Cameroon Hot Line is interpreted as a megashear zone, developed on both oceanic and continental domains [1]. The structure is characterized by a SW-NE alignment (trending $30^{\circ}$ ) of volcanic massifs and plutons extending from Pagalu Island to Lake Chad for more than $1600 \mathrm{~km}$. The general geology of Mount Etinde has been extensively described by [5]-[12] and the more recently summarized and updated by [13] [14] [15]. Its basement (Pan-African granite and gneisses) is covered by cretaceous to quaternary sediments [16]. The nephelinitic lavas erupted less 1Ma ago, and is contemporary with recent lavas of Mount Cameroon [17]. These rocks contain nepheline, clinopyroxene, garnet, melilite and post magmatic minerals such as sodalite, zeolite and analcite. Olivine occurs mostly in the olivine nephelinite where it makes up less $5 \mathrm{wt} \%$. Varieties of nephelinites are named on the basis of the dominant mineral and nepheline occurs.

\subsection{Analytical Method}

Mineral compositions were studied in detail and the compositional ranges given below are based on electron microprobe (CAMEBAX SX 50 at the University of Marie Curie, Paris) measurement of mafic phases in only a few representative sample of nephelinite. The measurement were made according to standard analyzed data, under the condition expressed in $\mathrm{kv}$ (acceleration) nA (beam current) and (counting times at the peak). Olivine (15 kv, $40 \mathrm{nA}, 20 \mathrm{~s}$ and $\mathrm{Si}$, clinopyroxene (15 kv, $40 \mathrm{nA}, 20 \mathrm{~s}$ for Si, $\mathrm{Al}, \mathrm{Fe}, \mathrm{Mg}, \mathrm{Ca}$, $\mathrm{Na} \mathrm{Mn}$ and $30 \mathrm{~s}$ for $\mathrm{Ti}$ and $\mathrm{Zr}$ ), nepheline ( $15 \mathrm{kv}, 40 \mathrm{nA}, 15 \mathrm{~s}$ for Si, Al, and $20 \mathrm{~s}$ for $\mathrm{Ca}$, $\mathrm{Na}, \mathrm{K}$ ), garnet (15 kv, $40 \mathrm{nA}, 20 \mathrm{~s}$ for $\mathrm{Si}, \mathrm{Al}, \mathrm{Fe}, \mathrm{Mg}, \mathrm{Ca}, \mathrm{Na}, \mathrm{Mn}$ and $15 \mathrm{~s}$ for Ti), melilite ((15 kv, $40 \mathrm{nA}, 20 \mathrm{~s}$ for al elements), perovskite and sphene ( $15 \mathrm{kv}, 40 \mathrm{nA}, 5 \mathrm{~s}$ for all 

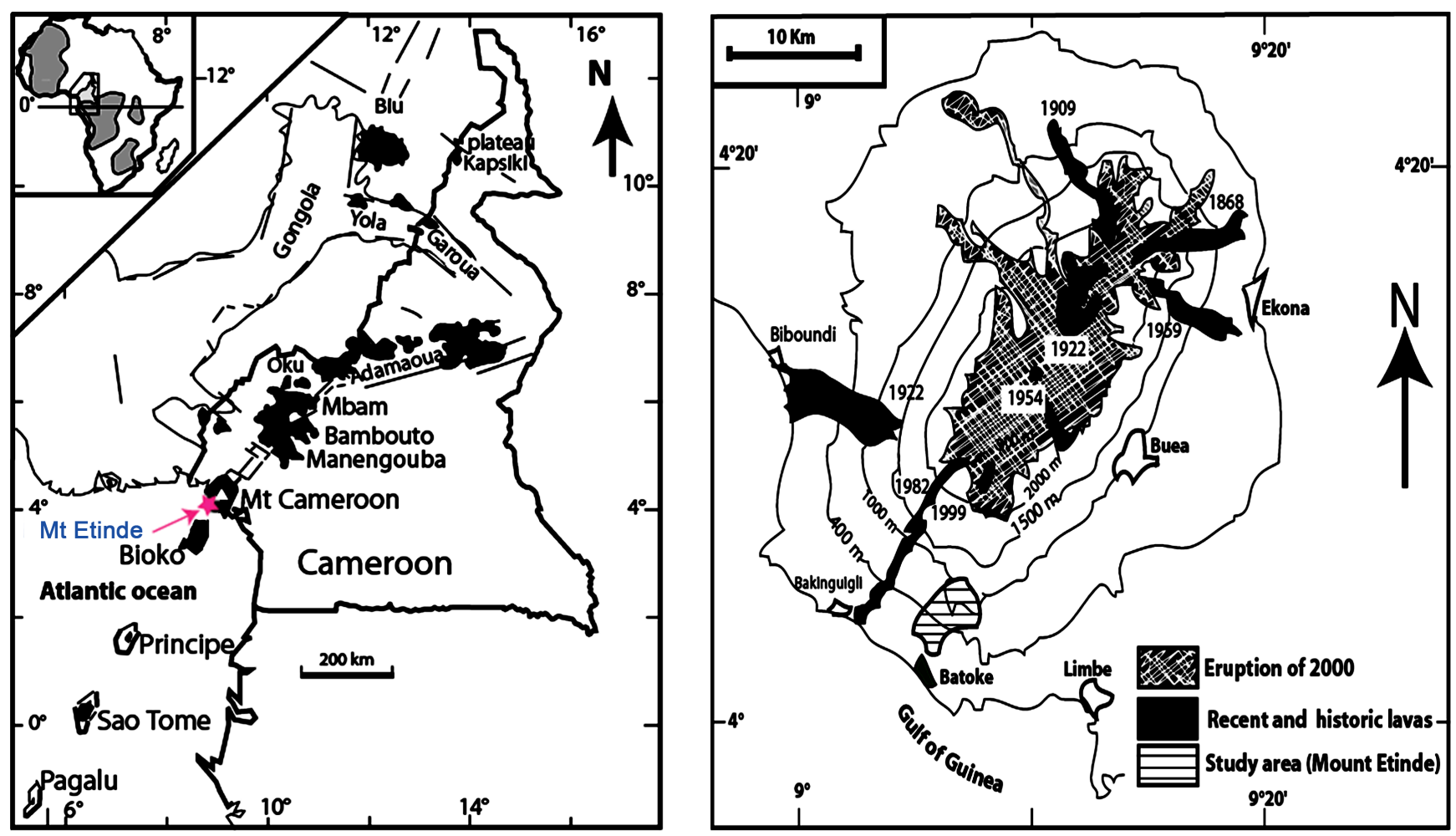

(a)

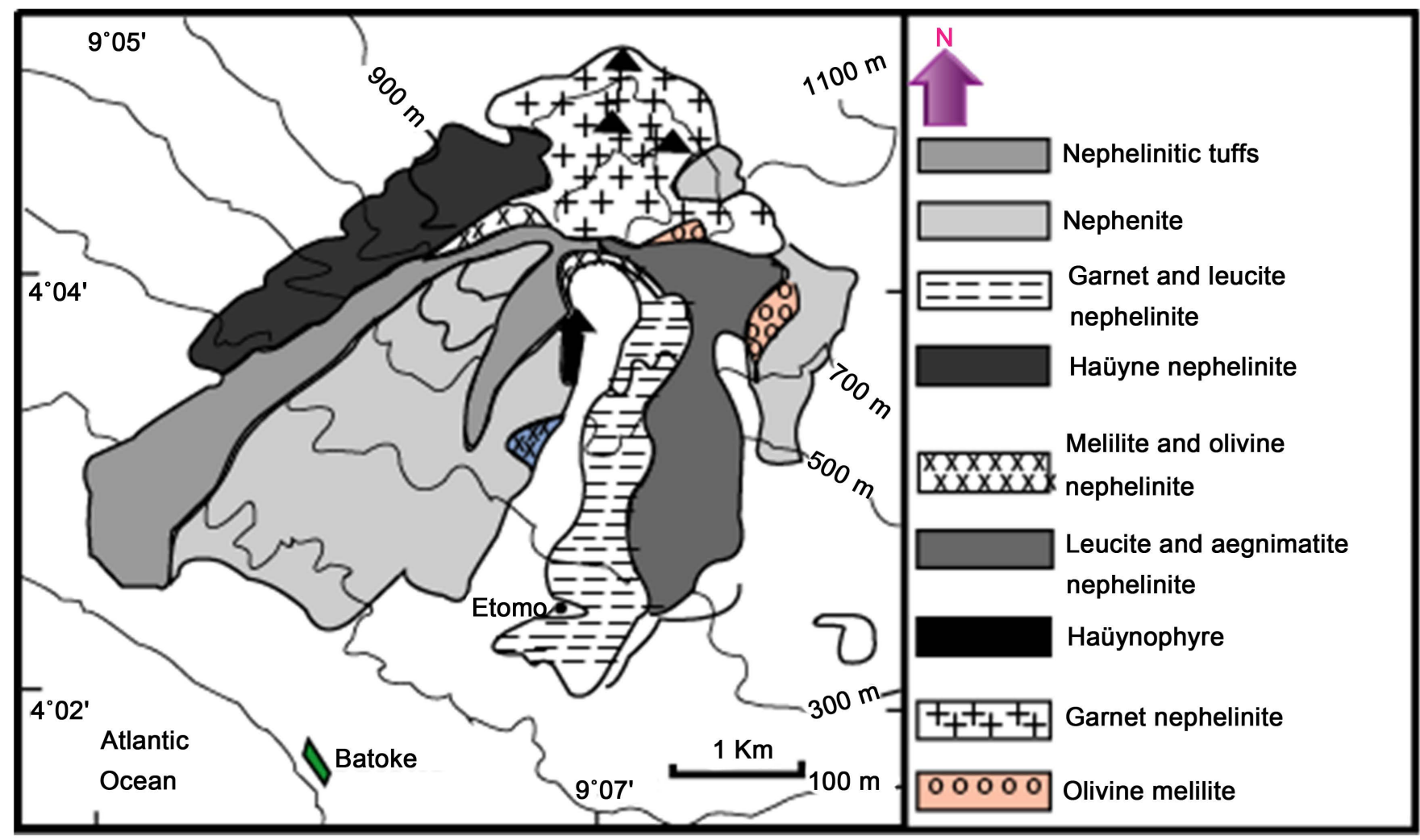

(b)

Figure 1. (a) Location of the study area, tectono-magmatic sitting of Mount Cameroon [1], (b) modified map of Etinde massif [12]. 
elements), (oxides (15 kv, $40 \mathrm{nA}, 20 \mathrm{~s}$ for Ti, Fe, Mn, Mg, $20 \mathrm{~s}$ for Si, $20 \mathrm{~s}$ for $\mathrm{Cr}$ and 30 $s$ for Al) natural silicates and oxides as standards, PAP corrections were made using CAMECA software [18]. Whole rock chemical analyses of peralkaline nephelinite from Etinde massif were carried out at the "Centre de Recherches Pétrographiques et Géochimiques" in Nancy. Major elements were analyzed by ICP-AES and trace elements by inductively coupled plasma mass spectrometry ICP-MS by Ngounouno.

\subsection{Experimental Methods}

Thermodynamic condition of crystallization during the eruption of Etinde nephelinite was determined by the QUILF95 software [19]. The programs application (QUILF thermobarometer) is explained by many works [20] [21] [22]. The minerals used for calculations, had not attained subsolidus re-equilibrium as showed by their unzoned and homogeneous compositions. Oxygen fugacity $\left(\mathrm{fO}_{2}\right)$ was calculated using the equation $\Delta \log F M Q=\operatorname{logfO} \mathrm{O}_{2}-\mathrm{FMQ}(\Delta \log \mathrm{FMQ} \leq 0)$. The experimental $\mathrm{aSiO}_{2}$ was calculated using the QUILF95 software from coexisting clinopyroxene, olivine and titano magnetite $\left(\mathrm{aSiO}_{2}=0.30-0.60\right)$. The experiments with an acceptable error $( \pm 0.02)$ gave the lowest values for $\mathrm{aSiO}_{2}$. Geothermobarometric calculations based on the composition of olivine, clinopyroxene and $\mathrm{Fe}$ - $\mathrm{Ti}$ oxide was used to determine the temperature range from $950^{\circ} \mathrm{C}$ to $1250^{\circ} \mathrm{C}$ at lower $\mathrm{fO}_{2}$.

\subsection{Petrography}

Our description of the nephelinite is based on samples collected from the flank of Mount Etinde and the Batoke beach, possibly representing the volcanic event. The textures are generally porphyritic ( $15 \%-30 \%$ phenocrysts), with groundmass exhibiting various textural types including intergranular, intersertal. Photomicrograph, taken under crossed polarizers, of nephelinte rocks shows olivine, clinopyroxene, nepheline and garnet phenocrysts. The photograph, taken plane polarized light, shows the typical shape of olivine and cliopyroxene: the irregular cracks and slight alteration along the craks (Figure 2(a) and Figure 2(c)). Clinopyroxene and nepheline are birefringent, garnet is black. The most nephelinitic lavas contains phenocrysts of Ca-rich clinopyroxene ( $<20$ vol\%), titanomagnetite $(<2$ vol $\%)$ and in some samples, melilite $(<5$ vol $\%)$. Nepheline phenocrysts occurring in some of these nephelinitic rocks is automorphic (Figure 2(b)). They are coarse grained and consist of euhedral to subhedral nepheline (typically replaced by cancrinite alteration product), altered formed haüyne or nosean, and alkali feldspar. Some olivine crystals are surrounded by rims of diopside. These rocks contain rare, resorbed phenocrysts of olivine surrounded by clinopyroxene as well as magnetite. The clinopyroxene phenocrysts are subhedral to euhedral and reach a few millimeters in size. At the contact with these interstitial domains, the brown diopside phenocrysts are transformed into green hedenbergite with a composition that matches that of groundmass pyroxene. Some clinopyroxene show zoning (Figure 2(a)). This characteristic has previously been reported, [9] [12] [13] [23]. Ti-magnetite is common, and partly altered olivine and haüyne are present in haüyne nephelinitic and 


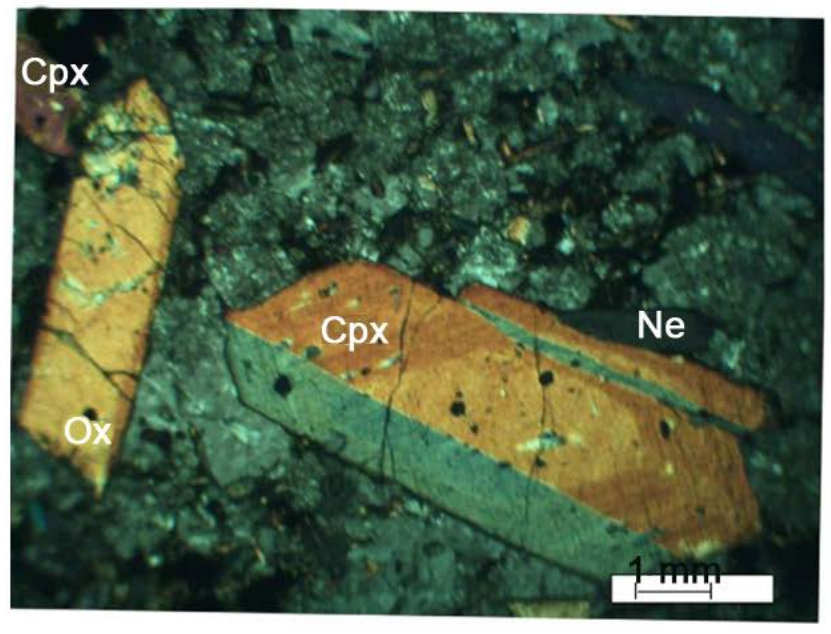

(a)

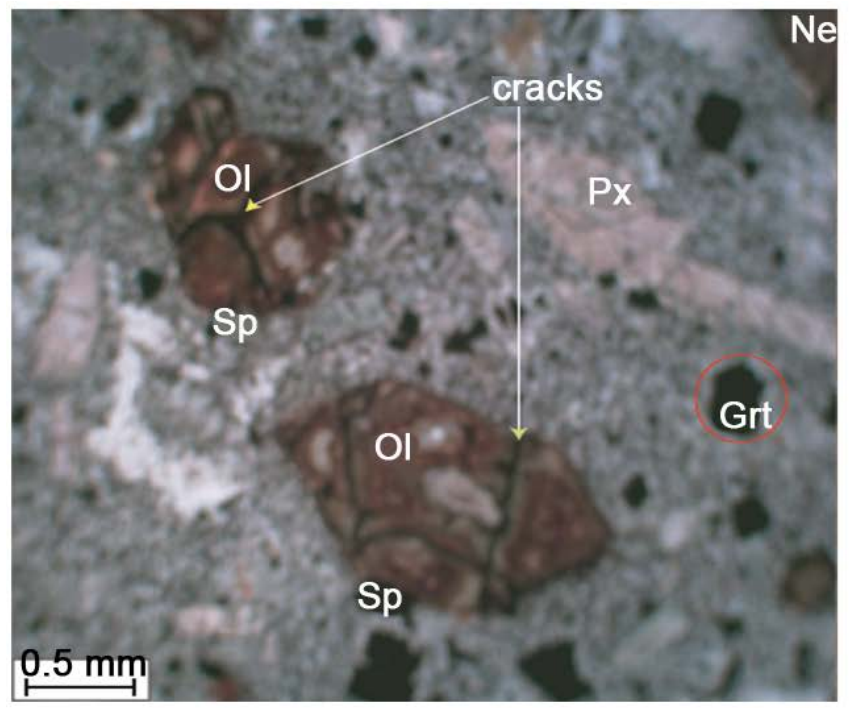

(c)

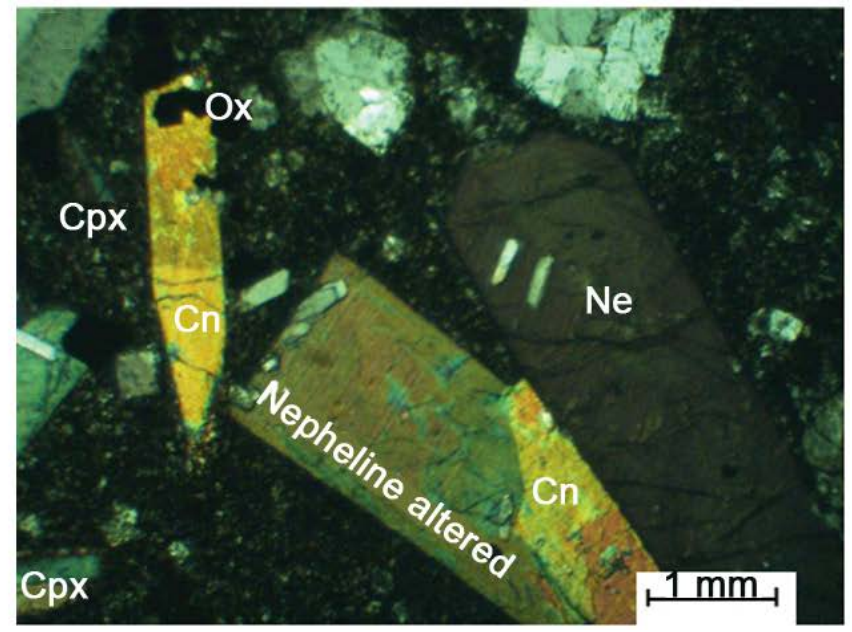

(b)

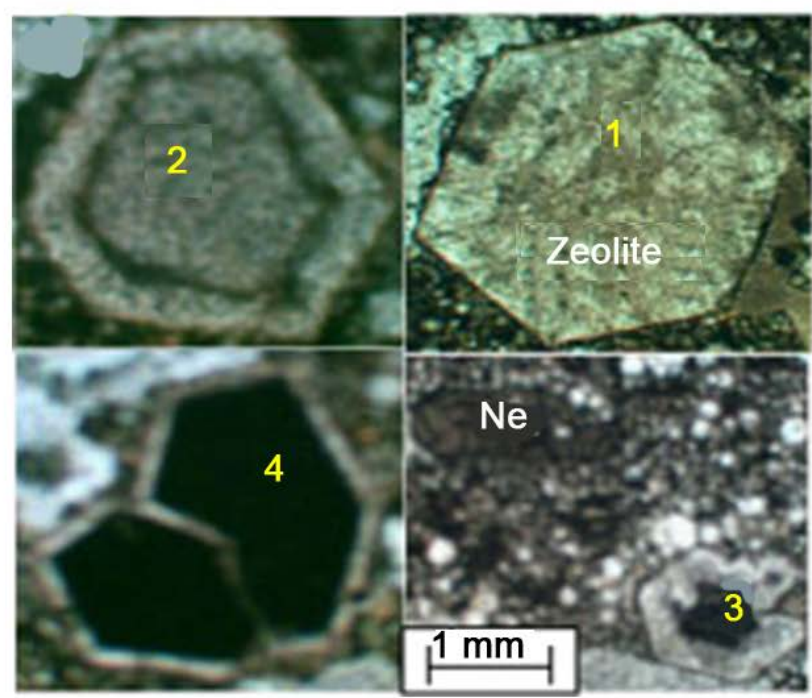

(d)

Figure 2. Photomicrograph (plane polarized light) of layer, illustrating the occurrence of oxyde. Garnet, (grt), cancrinite (cn), nepheline (ne) and clinopyroxene (cpx) are also in the field of view.

haüynophyre. Spinel, described here from the nephelinitic lavas, occurs as tin (up to 2 $\mathrm{mm}$ ) opaque or brownish euhedral inclusions in olivine and euhedral inclusions in aluminous clinopyroxene. Spinels found are xenomorphic, probably because it crystallized late. Small magnetites are irregularly distributed between the silicates, the locally form lenticular zones of interstitial Ti-magnetite. The groundmass consists of prismatic clinopyroxene and nepheline up to $0.2 \mathrm{~mm}$ in length microphenocrysts set in a matrix with smaller crystals, perovskite, magnetite, sphene and carbonate. The prismatic Zeolite is automorphe in LPA and replaced by analcime product (Figure 2(d)). The minor and accessory phases include zeolite, analcime, magnetite, apatite and perovskite. In additional, spinel is the most common accessory mineral but it is usually pale to dark brown. Groundmass is frequently altered and consists of a low temperature assemblage 
of zeolite, which probably replace feldspar \pm nepheline. Melilite microphenocrysts occur in a green-grey aphanitic textural in melilite nephelinite. Groundmass clinopyroxene grains are up to $0.5 \mathrm{~mm}$ in size.

\section{Mineral Chemistry}

Selected electron microprobe analyses of pyroxene and garnet phenocrysts are represented in the figure. These data are plotted on conventional Diopside-Hedenbergite-EnstatiteFerrosilite and Almandine-Pyrope-Spertartine quadrilateral and ternary diagrams, respectively, comparing the current results against previously published data from the Etinde Mountain [11] [12] [13].

Rage homogeneous olivine grains in the néphélinite are $\mathrm{Mg}$-rich $\left(\mathrm{Fo}_{86}\right)$ and moderately high levels of $\mathrm{CaO}$ content solid-solution, and are similar composition to olivine grain from xenolith

\subsection{Pyroxene}

The nomenclature of [24] was used for pyroxene. Chemical analyses of pyroxene were plotted on the quadrilateral classification diagram Di-Hd-En-Fs. The result reveals three clinopyroxene types in the Etinde massif, magnesium-rich diopside $\mathrm{Wo}_{49-52} \mathrm{En}_{23-47} \mathrm{Fs}_{4-17}$, hedenbergite $\mathrm{Wo}_{50-47} \mathrm{En}_{13-11} \mathrm{Fs}_{37-32}$ and augite $\mathrm{Wo}_{44-47} \mathrm{En}_{17-23} \mathrm{Fs}_{14-17}$ (Table 1), the diopside has $\mathrm{Mg}$ \# [=atomic $\left.100 \times \mathrm{Mg}^{2+} /\left(\mathrm{Mg}^{2+}+\mathrm{Fe}^{2+}+\mathrm{Mn}^{2+}\right)\right]$ ranging between 0.63 and 0.71$)$. Moreover, clinopyroxene crystals display a trend of decreasing En and Wo with increasing Fs on the quadrilateral classification diagram. Clinopyroxene is low in calcium, $0.73-0.83$ atoms per formula unit (a.p.f.u.), and contains significant $\mathrm{Al}(0.23-0.39$ a.p.f.u.). It consists of a relatively large diopsidic core that is relatively Ca-poor and $\mathrm{Na}$-rich, and exhibits large differences in $\mathrm{Al}$ content from grain to grain (mg-number $0.78-0.83$ ) (Figure 3).

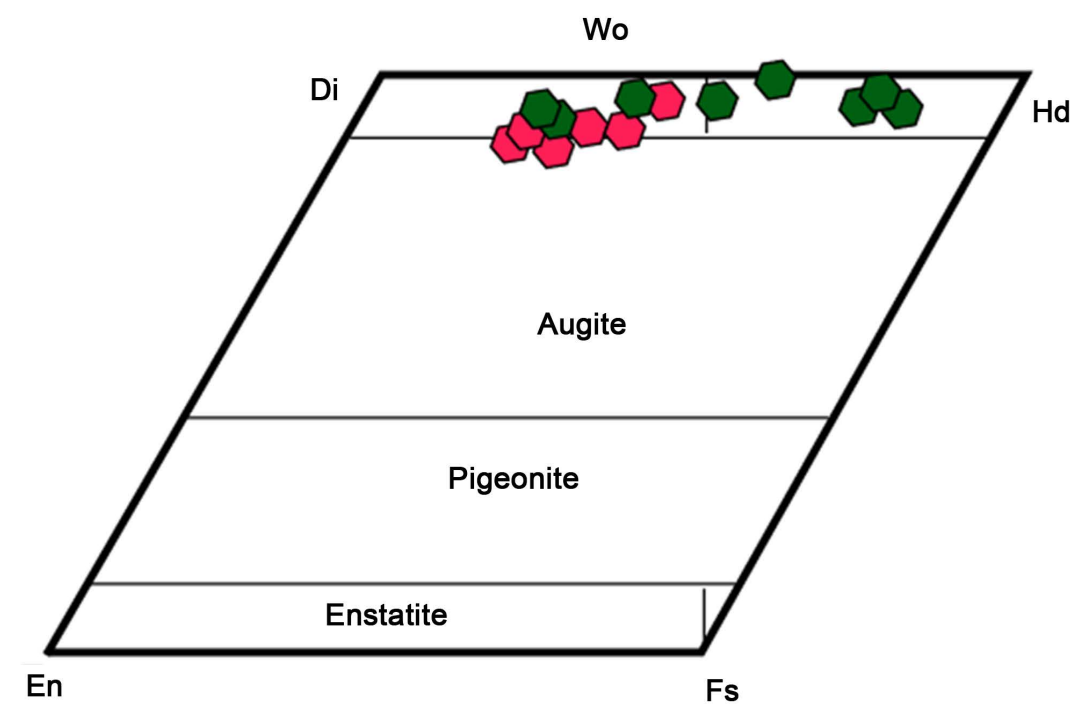

Figure 3. The quadrilateral classification diagram of clinopyroxene [24]. 
Table 1. Clinopyroxene in pyroxene nephelinite.

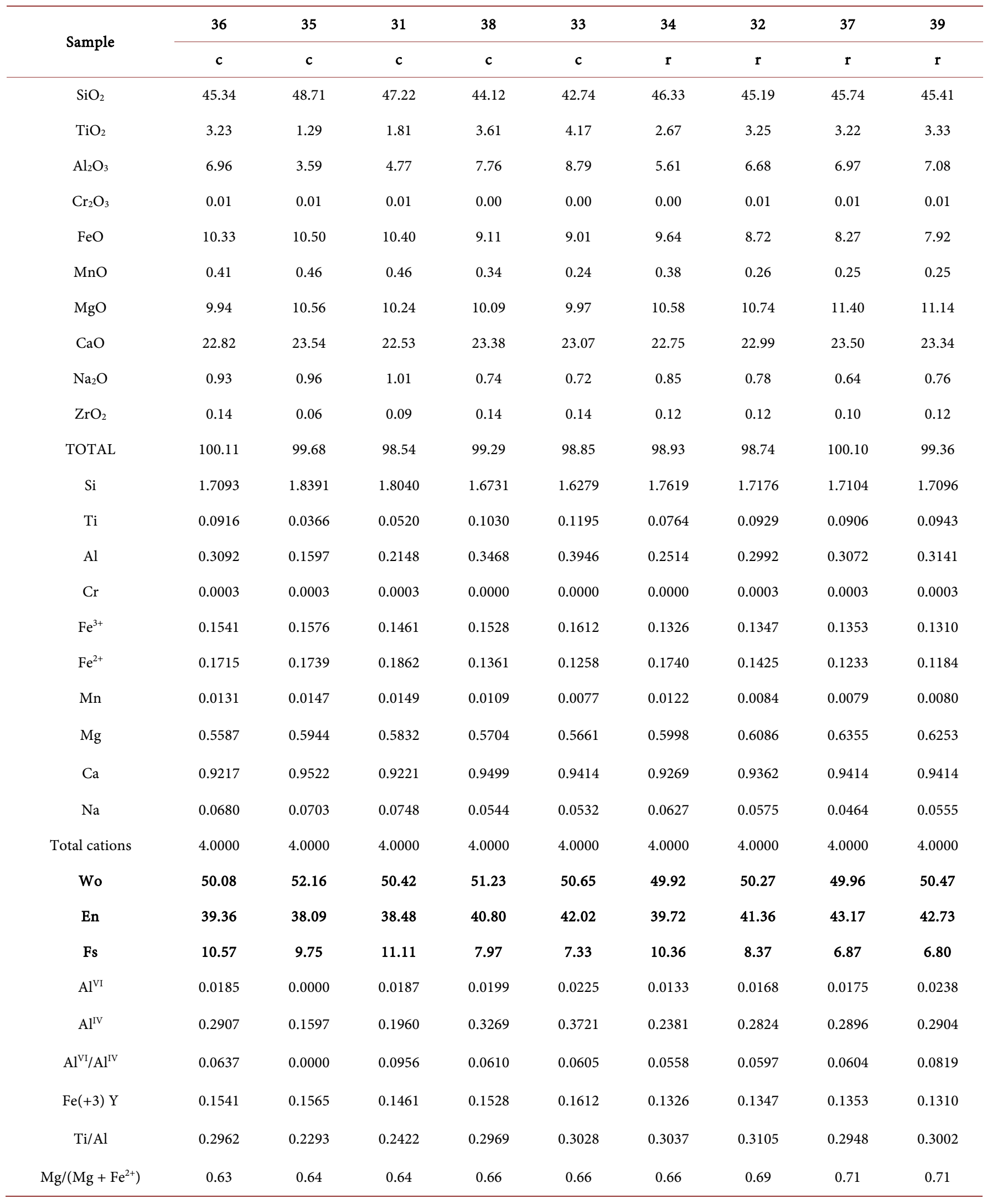




\subsection{Garnet}

Garnet composition falls within the compositional range of garnets reported in other lavas and ijolites from Oldoinyo Lengai [25], and nephelinite from Tanzania [3]. There are no significant differences in the compositions of the garnets from the different nephelinite varieties at Etinde. The main compositional variations are in the amounts of $\mathrm{Ti}$ and total $\mathrm{Fe}$, which vary inversely. The minor elements, $\mathrm{MnO}(<1 \%)$ and $\mathrm{ZrO}_{2}$ $(<1 \%)$, present concentrations in appreciable amounts. Garnet is andratite rich, with an overall compositional range of $\mathrm{And}_{72-43} \operatorname{Pr}_{7-11}, \mathrm{Uva}_{0,1-0.54} \mathrm{Sps}_{4-10}$, and $\mathrm{Grs}_{13-44}$ (Figure 4). The $\mathrm{TiO}_{2}$ contents are low, varying from 7 to $14 \mathrm{wt} \%$.

\subsection{Haüyne}

Representative chemical analyses and structural formulae $\left(\mathrm{O}^{2-}=21\right)$ of haüyne is presented in Table 2. Ternary diagram (Figure 5) shows that haüyne data are similar to those of pan de AZUCAR haüyne [27]. The diagram of the system reveals that Haüyne has $\mathrm{CaO}$ concentration ranging between 60 and $80 \mathrm{wt} \%$.

\subsection{Perovskite and Sphene}

Perosvkite and Sphene are trace- and rare element-rich. The Trace elements content

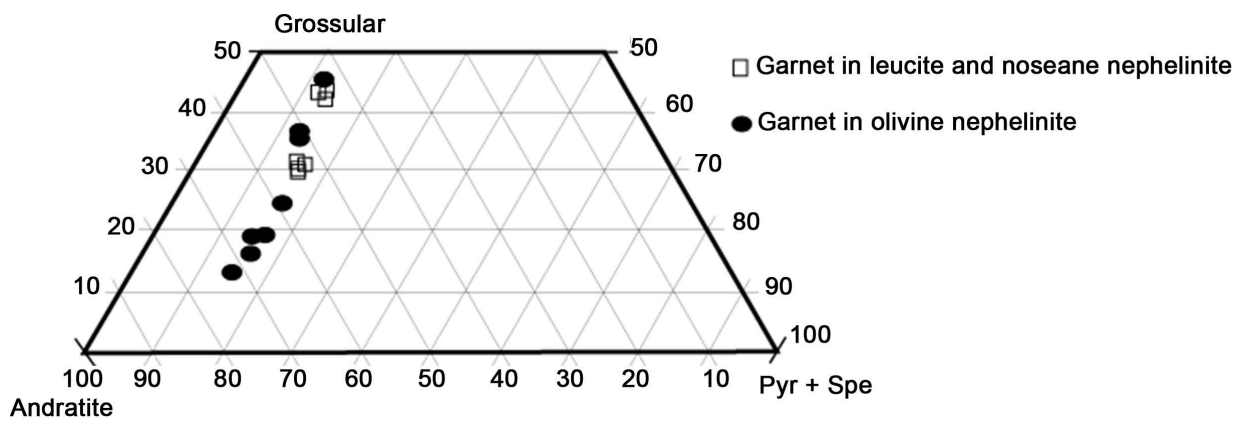

Figure 4. Ternary classification diagrams after [26].

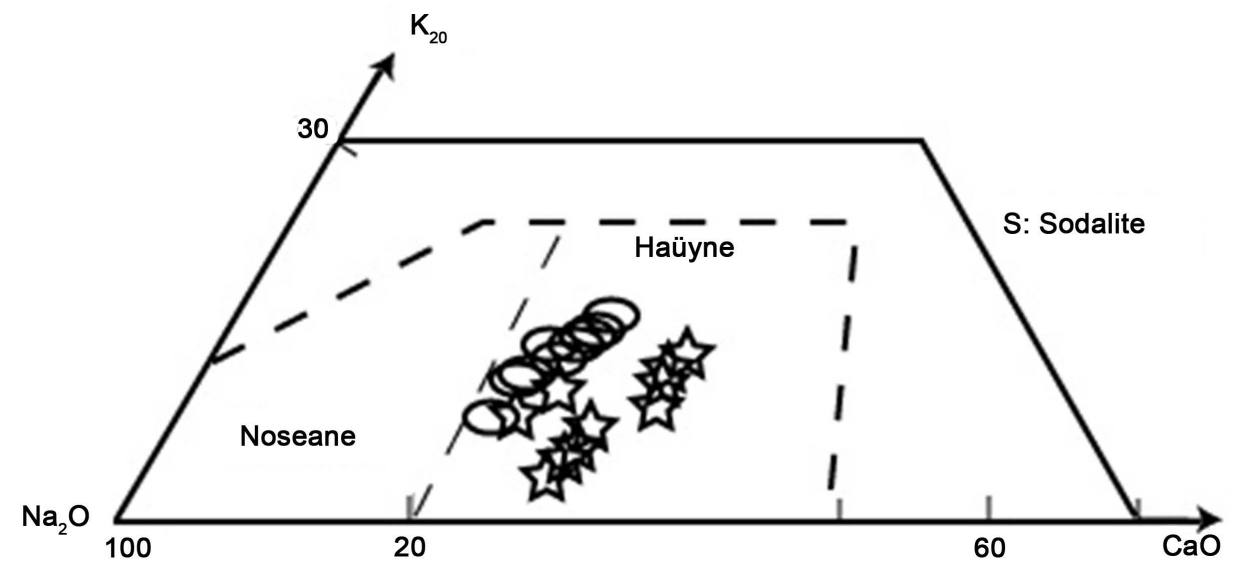

Figure 5. Ternary classification diagrams of feldspathoid after [28]. The round and star represent respectively haüyne of Mount Etinde and the lavas flow in Pan de Azúcar 2 series [27]. 
Table 2. Major and minor element compositions of Haüyne phenocrysts of Haüynopyre.

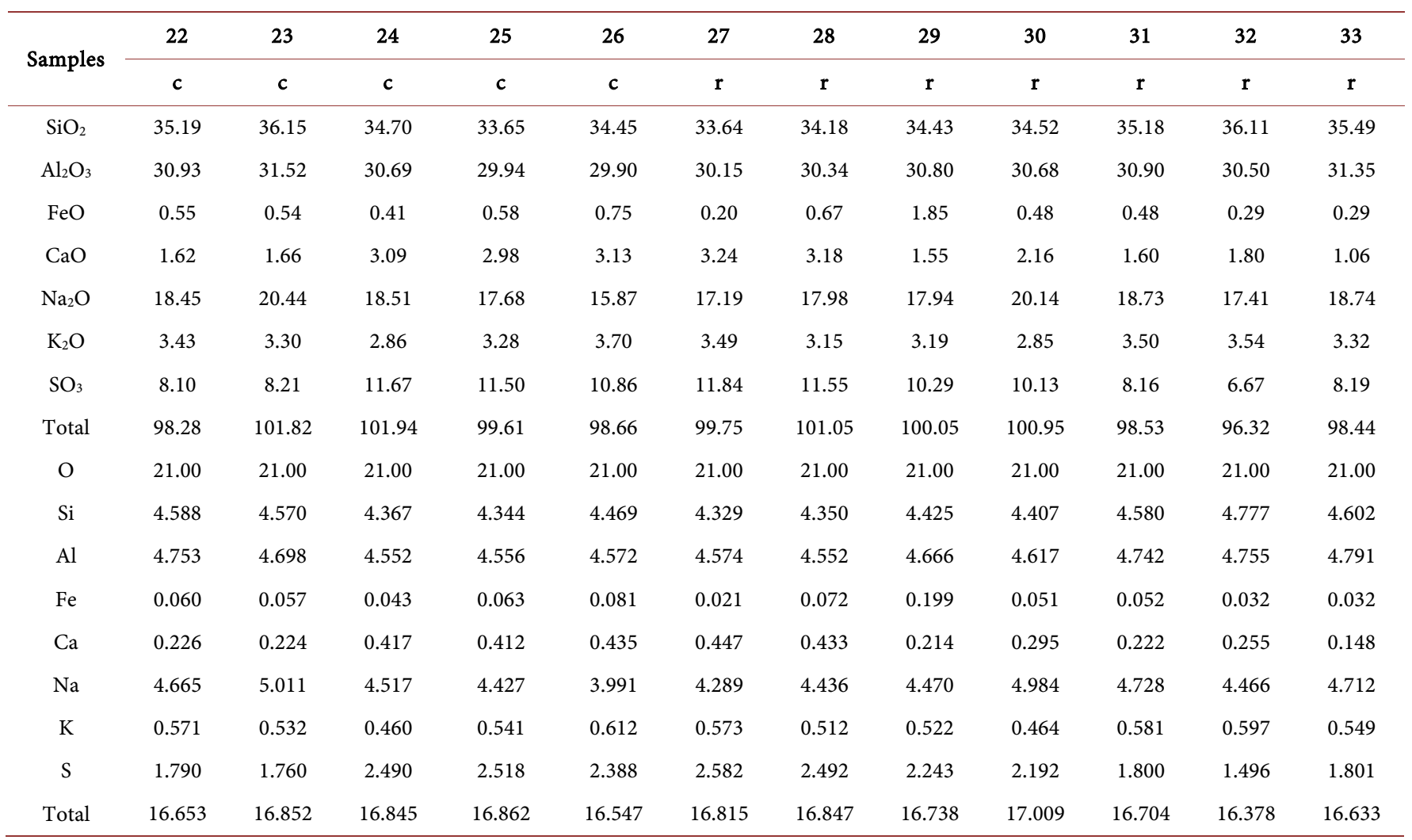

( $\mathrm{BaO}, \mathrm{SrO}, \mathrm{ZrO}_{2}$ and $\mathrm{Nb}_{2} \mathrm{O}_{3}$ ) represented slightest $4.0 \mathrm{wt} \%$. Sphene's rare elements content is low $\approx 2 \mathrm{wt} \%$, and for perovskite they vary between $3-8 \mathrm{wt} \%$. The ternary classification $\mathrm{CaO}-\mathrm{SiO}_{2}-\mathrm{TiO}_{2}$ diagrams shows that the crystallization temperature condition of sphene is low compared to perovskite [29]. The phase diagram of the system reveals that perosvkite contains $40 \mathrm{wt} \% \mathrm{Cao}$ and $60 \mathrm{wt} \% \mathrm{TiO}_{2}$.

\section{Nepheline}

Phenocryst cores contain around $19-22 \mathrm{~mol} \%$ kalsilite (Ks) and generally contain excess Si. Although some cores are homogeneous, others are complex, with zones containing differing $\mathrm{K}$ and $\mathrm{Fe}$ concentrations. Enrichment in $\mathrm{K}$ and $\mathrm{Fe}$ is a feature of the rims seems of nepheline described by [25]. Over all, the nepheline in olivine nephelinite is more potassic (around 25\% - 27\% Ks molecule) than in the other nephelinite (20\% $25 \% \mathrm{Ks}$ ). Nepheline from the $0.2 \mathrm{GPa}$ experiments has a relatively restricted compositional range, with an average composition of $\mathrm{Ne}_{77-74} \mathrm{Ks}_{19-2} \mathrm{Qz}_{3-4}$. Fresh nepheline shows a very constant composition close to $\mathrm{Ne}_{77} \mathrm{Ks}_{19} \mathrm{Qz}_{3}$, whereas in type nepheline, it has a lower proportion of quartz.

\subsection{Spinel}

Spinels chemical compositions were calculated on the basis of three cations and the proportions of $\mathrm{Fe}^{3+}$ and $\mathrm{Fe}^{2+}$ were determined on the basis of charge balance [30]. The 
high $\mathrm{Al}_{2} \mathrm{O}_{3}$ content indicates the low silicate activity [31]. Spinel is relatively poor in $\mathrm{Cr}$ and rich in $\mathrm{Al} . \mathrm{Al}_{2} \mathrm{O}_{3}$ content varies from 58 to $59 \mathrm{wt} \%, \mathrm{MgO}$ (18 - $19 \mathrm{wt} \%$ ) and $\mathrm{FeO}$ (17 - 18wt\%). This indicates that they were crystallized from an alkaline magma. Spinel type is pleonaste (Figure 6) and it is similar to the spinel which is included in clinopyroxenes at Oldoinyo Lengai, Tanzanie [4].

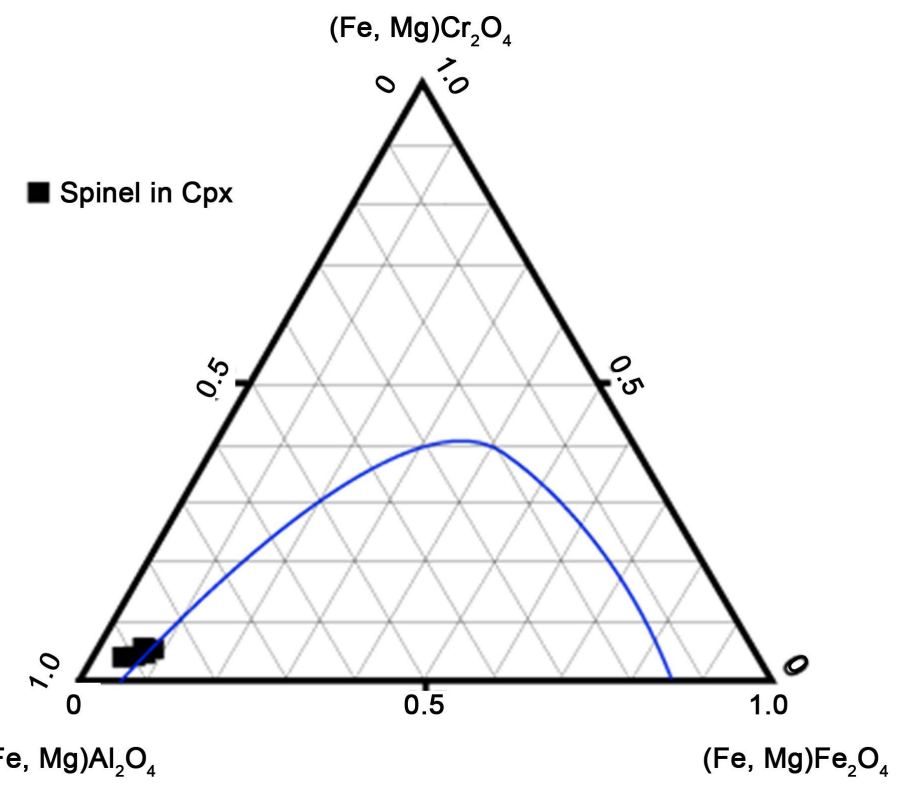

Figure 6. Ternary plot of spinel diagram [32].

\subsection{Melilite}

The minerals of the melilite group consist mainly of the solid-solution series between åkermanite $\left(\mathrm{Ca}_{2} \mathrm{MgSi}_{2} \mathrm{O}_{7}\right)$, gehlenite $\left(\mathrm{Ca}_{2} \mathrm{Al}_{2} \mathrm{SiO}_{7}\right)$ and ferro-akermanite $\left(\mathrm{Ca}_{2} \mathrm{Fe}^{2+} \mathrm{Si}_{2} \mathrm{O}_{7}\right)$. The most melilite however contain appreciable amounts of $\mathrm{Na}$ replacing $\mathrm{Ca}$ as well as $\mathrm{Fe}^{2+}$ replacing $\mathrm{Mg}$ [28]. The melilite has been found only as microphenocrysts in melilite nephelinite and rare olivine nephelinite. They are iron and soduim rich $\left(\mathrm{Fe}_{2} \mathrm{O}_{3} 6\right.$ to $\sim 9 \mathrm{wt} \%$; $\mathrm{Na}_{2} \mathrm{O} 5$ - $\left.6 \mathrm{wt} \%\right)$. Melilite containing up to $6.0 \mathrm{wt} \% \mathrm{SrO}$. The compositional variations are slightest fairly that melilite in small olivine melilitite lavas flows on the floor of the rift valley to the east of Oldoinyo Lengai [25]. Ternary Diagrams [33] shows that composition corresponds to intermediate members of the ferro-akermmanite and Gehlenite.

\section{Whole-Rock Chemistry}

The variations observed in the major element composition (Table 1) could be partly explained by fractional crystallization processes. These variations are consistent with fractional processes dominated by removal of clinopyroxene, Ti-magnetite. Compared with other member nephelinite rock of the Oldoinyo Lengai silicate lava suite [34], the late nephelinites have the lower $\mathrm{SiO}_{2}$ and $\mathrm{Al}_{2} \mathrm{O}_{3}$ contenent but the highest total iron, $\mathrm{Cl}$ and $\mathrm{F}$ concentrations. The nephelinite rocks are lower in the pneumotophile elements 
concentration ( $\mathrm{Cl}, \mathrm{Na}, \mathrm{Fe}, \mathrm{Mn}, \mathrm{P}$, and $\mathrm{Ti})$. The low $\mathrm{MgO}$ ( $<2 \mathrm{wt} \%), \mathrm{Ni}(<15 \mathrm{ppm})$ and $\mathrm{Cr}(<12 \mathrm{ppm})$ concentrations indicate that these are evolved lavas. It also has $\mathrm{Al}_{2} \mathrm{O}_{3}$ concentrations similar to the other late nephelinite and despite the presence of Fe-rich rims on nepheline, sodalite and pyroxene phenocrysts.

\subsection{Major Element}

On the Harker diagram (Figure 7) with increasing $\mathrm{MgO}$ contents, $\mathrm{TiO}_{2}, \mathrm{FeO}$ and $\mathrm{CaO}$ contents generally increase and $\mathrm{CaO} / \mathrm{Al}_{2} \mathrm{O}_{3}$ ratios are relatively constant at $\mathrm{MgO}<6$ $\mathrm{wt} \%$ indicating olivine as the dominant crystallizing phase. Slightly positive correlations between $\mathrm{MgO}$ vs $\mathrm{FeO}, \mathrm{MgO}$ vs $\mathrm{CaO}$ and $\mathrm{TiO}_{2}$ a negative correlation between $\mathrm{MgO}$ is observed at $5.5 \mathrm{wt} \% \mathrm{MgO}$. An interesting phenomenon is that when $\mathrm{MgO}$ contents are between 5.5 and $10.0 \mathrm{wt} \%, \mathrm{Al}_{2} \mathrm{O}_{3}$ contents show a negative correlation with $\mathrm{MgO}$ whereas $\mathrm{P}_{2} \mathrm{O}_{5}$ contents exhibit a slightly positive correlation with $\mathrm{MgO}$. It is possible that the high $\mathrm{Al}_{2} \mathrm{O}_{3}$ ( $\geq 19$ wt\%) contents of the more $\mathrm{SiO}_{2}$-rich, $\mathrm{MgO}$-poor samples could be result of a process superimposed upon simple fractional crystallization.

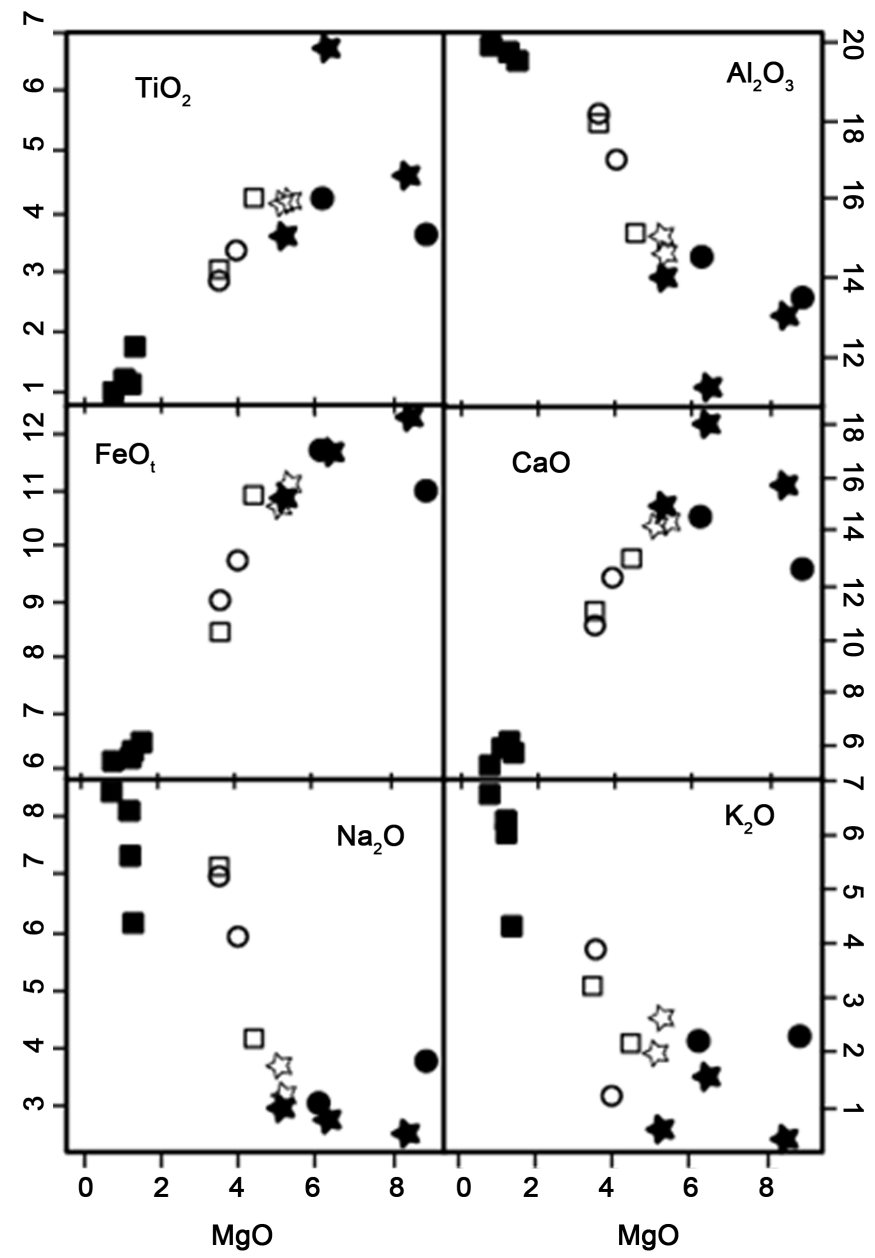

Figure 7. Major element contents and their ratios against $\mathrm{MgO}$ variation diagrams for bulk rocks: $\mathrm{TiO}_{2}$ versus $\mathrm{MgO}, \mathrm{Al}_{2} \mathrm{O}_{3}$ versus $\mathrm{MgO}, \mathrm{CaO}$ versus $\mathrm{MgO}, \mathrm{Na}_{2} \mathrm{O}$ versus $\mathrm{MgO}$. 


\subsection{Trace Element Whole-Rock Compositions}

Trace element analyses of the nephelinite from Etinde massif are reported in Table 3 and illustrated in primitive mantle-normalized diagrams (Figure 8).They are enriched in large ion lithophile elements (LILE, $\mathrm{Rb}, \mathrm{Ba}$, and $\mathrm{Sr}$ ) and depleted in $\mathrm{Ti}$ (high-field strength elements, HFSE). They are also depleted in heavy rare earth elements (HREE) and enriched in light rare earth elements (LREE) relative to HREE. These trace element distribution patterns are similar to that of Oldoinyo Lengai nephelinite and the alkaline lavas of Cameroon Hot Line [1]. The trace element patterns of olivine nephelinite, melilitite and perovskite nephelinite are very similar (parallel) and characterized by a weak slightly positive $\mathrm{Zr}$ anomaly (Figure 8 ). The primitive mantle normalized trace element patterns of the nephelinite show negative $\mathrm{P}, \mathrm{K}$, and Ti anomaly. In detail, however, the

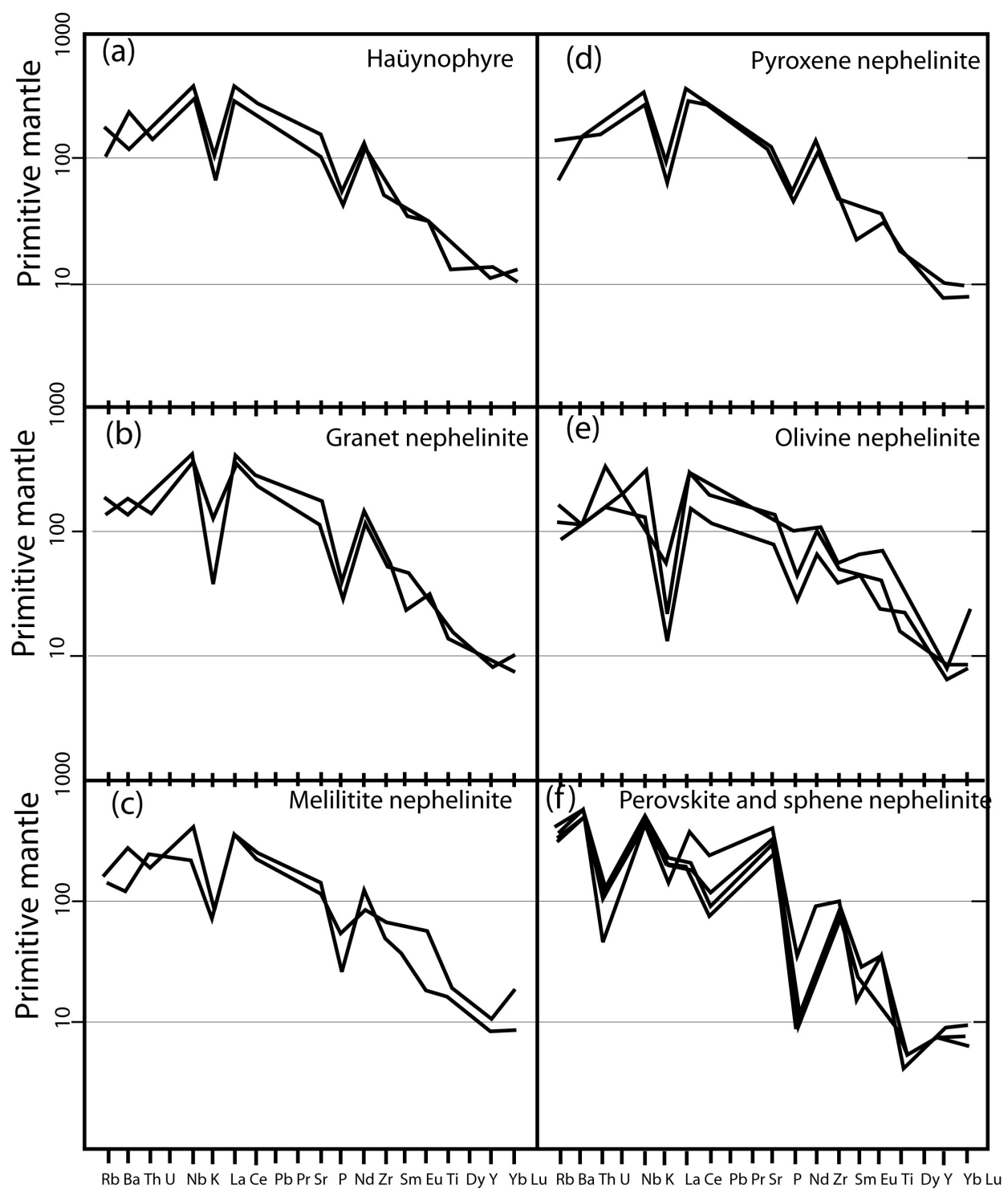

Figure 8. Multi-element diagrams normalized trace element and rare element plot for representative rocks; normalization values are from [42]. 
Table 3. Whole rock chemical composition of the nephelinitic lavas representative from mount etinde analysis.

\begin{tabular}{|c|c|c|c|c|c|c|c|c|c|c|c|c|c|c|c|}
\hline & \multicolumn{2}{|c|}{$\begin{array}{c}\text { Pyroxene } \\
\text { nephelinite }\end{array}$} & \multicolumn{2}{|c|}{$\begin{array}{c}\text { Melilite } \\
\text { nephelinite }\end{array}$} & \multicolumn{3}{|c|}{$\begin{array}{c}\text { Olivine } \\
\text { nephelinite }\end{array}$} & \multicolumn{2}{|c|}{$\begin{array}{c}\text { Garnet } \\
\text { nephelinite }\end{array}$} & \multicolumn{4}{|c|}{$\begin{array}{l}\text { Perovskite } \\
\text { nephelinite }\end{array}$} & \multicolumn{2}{|c|}{ haüynorphyre } \\
\hline & ME35 & ME24 & ME133 & ME135 & ME12 & ME134 & ME34 & ME158 & ME152 & ME153 & ME36 & ME154 & ME155 & ME132 & ME32 \\
\hline $\mathrm{SiO}_{2}$ & 40.66 & 39.92 & 41.40 & 40.00 & 36.69 & 39.20 & 40.01 & 41.20 & 40.16 & 43.59 & 43.54 & 43.34 & 44.19 & 39.89 & 40.23 \\
\hline $\mathrm{TiO}_{2}$ & 4.15 & 4.14 & 3.60 & 4.21 & 6.77 & 4.60 & 3.62 & 3.31 & 2.93 & 2.00 & 2.09 & 2.11 & 2.75 & 2.98 & 4.23 \\
\hline $\mathrm{Fe}_{2} \mathrm{O}_{3}$ & 12.00 & 12.28 & 12.20 & 13.00 & 13.02 & 13.69 & 12.06 & 10.85 & 10.00 & 7.80 & 7.97 & 7.73 & 7.20 & 9.40 & 12.12 \\
\hline $\mathrm{MnO}$ & 0.20 & 0.33 & 0.20 & 0.22 & 0.30 & 0.24 & 0.43 & 0.40 & 0.31 & 0.65 & 0.37 & 0.27 & 0.96 & 0.22 & 0.24 \\
\hline $\mathrm{MgO}$ & 5.12 & 5.25 & 8.90 & 6.23 & 6.40 & 8.40 & 5.22 & 3.98 & 3.55 & 0.78 & 1.20 & 1.23 & 1.38 & 3.50 & 4.44 \\
\hline $\mathrm{CaO}$ & 14.20 & 14.34 & 12.60 & 14.56 & 18.20 & 15.77 & 14.78 & 12.33 & 10.46 & 6.20 & 6.12 & 6.22 & 5.79 & 11.01 & 12.98 \\
\hline $\mathrm{P}_{2} \mathrm{O}_{5}$ & 1.22 & 1.08 & 0.60 & 1.21 & 2.20 & 0.63 & 1.01 & 0.65 & 0.76 & 0.16 & 0.20 & 0.17 & 0.83 & 1.00 & 1.12 \\
\hline $\mathrm{SO}_{3}$ & 0.04 & 0.22 & & & & & 0.12 & & 2.2 & 0.12 & 0.43 & 0.21 & & 2.02 & 0.02 \\
\hline $\mathrm{Cl}$ & 0.01 & 0.11 & & & & 0.05 & 0.04 & 0.01 & 0.3 & 0.23 & 0.39 & 0.57 & 6.29 & 0.4 & 0.03 \\
\hline $\mathrm{PF}$ & 1.08 & 1.42 & & 2.19 & 1.21 & 1.33 & 5.2 & 2.45 & 0.56 & 1.52 & 2.2 & 3.11 & & 0.78 & 2.44 \\
\hline Total & 99.34 & 99.44 & 99.00 & 101.35 & 100.21 & 99.73 & 100.13 & 99.26 & 100.17 & 99.17 & 99.50 & 99.04 & 99.30 & 99.49 & 99.35 \\
\hline $\mathrm{Ba}(\mathrm{ppm})$ & 1003 & 1078 & 1858 & 826 & 781 & 766 & 795 & 1168 & 1011 & 3272 & 2903 & 3500 & 2999 & 889 & 1700 \\
\hline $\mathrm{Rb}$ & 47 & 93 & 100 & 96 & 55 & 77 & 100 & 94 & 115 & 248 & 221 & 199 & 232 & 108 & 73 \\
\hline $\mathrm{Ni}$ & 12 & 13 & 14 & 23 & 25 & 45 & 22 & 7 & 9 & 3 & 4 & 3 & $\mathrm{Na}$ & 10 & 14 \\
\hline Co & 43 & 38 & 23 & 66 & 87 & 37 & 33 & 38 & 17 & 19.2 & 41 & 55 & 122 & 24 & 51 \\
\hline $\mathrm{Zn}$ & 121 & 141 & 138 & 85 & 97 & 102 & 147 & 129 & 154 & 222 & 222 & 211 & $\mathrm{Na}$ & 142 & 149 \\
\hline $\mathrm{Cr}$ & 8 & 9 & 13 & $\mathrm{Na}$ & $\mathrm{Na}$ & 113 & 27 & 7 & 4 & 3 & 6 & 4 & $\mathrm{Na}$ & 4 & 12 \\
\hline $\mathrm{La}$ & 214 & 256 & 233 & 219 & 205 & 103 & 193 & 281 & 237 & 114 & 143 & 136 & 233 & 232 & 266 \\
\hline $\mathrm{Ce}$ & 467 & 501 & 456 & 392 & 431 & 211 & 366 & 503 & 434 & 131 & 192 & 157 & 417 & 444 & 487 \\
\hline $\mathrm{Nd}$ & 172 & 187 & 163 & 111 & 141 & 89 & 149 & 185 & 154 & 26 & 47 & 39 & 122 & 155 & 160 \\
\hline $\mathrm{Sm}$ & 19 & 10 & 15 & 26 & 30 & 19 & 19 & 10 & 20 & 7 & 12 & 10 & 11 & 18 & 16 \\
\hline $\mathrm{Eu}$ & 6.1 & 5.1 & 3.2 & 9.1 & 11.8 & 4 & 6.9 & 5 & 5.1 & 6.3 & 5.7 & 3.8 & $\mathrm{Na}$ & 4.8 & 5.02 \\
\hline $\mathrm{V}$ & 243 & 225 & 297 & 245 & 287 & 222 & 133 & 267 & 289 & 304 & 288 & 233 & 376 & 244 & 289 \\
\hline $\mathrm{Yb}$ & 4 & 4.3 & 4.5 & 9.1 & 11.8 & 4 & 3.89 & 4.6 & 3.6 & 4.6 & 3.5 & 3.36 & $\mathrm{Na}$ & 5.1 & 5.4 \\
\hline $\mathrm{Y}$ & 36 & 42 & 39 & 48 & 36 & 29 & 37 & 36 & 41 & 42.7 & 36 & 32 & 33 & 56 & 51 \\
\hline
\end{tabular}


negative $\mathrm{Nb}$ anomaly is more significant for Etinde. They also show small $\mathrm{Zr}$ and $\mathrm{Y}$ positive anomalies where as small negative anomalies for these two elements are observed in the olivine nephelinite.

Nephelinite rocks has lower overall REE abundances compared with the haüynophyre, exhibiting different concave up REE pattern with steeper LREE part $(\mathrm{La} / \mathrm{Sm})=$ 18 compared with 4 - 5 in nephelinite. The trace element profile resembles that of nepheline from the Tanzania alkaline complex [4]. The total REE concentration and the slope of primitive normalized distribution patterns $(\mathrm{La} / \mathrm{Sm})$ ratios increase with differentiation. None of the samples analyzed for REE shows a significant Eu anomaly and this suggest no fractionation of plagioclase.

\subsection{Mantle Source and Geodynamic Implications}

Primitive mantle-normalized trace-element patterns of Etinde samples (Figure 8 and Table 3 for values) show sub-parallel shapes. The trace elements display a limited range of variations, indicating little influence of fractional crystallization differentiation. The samples nephelinite shows a negative $\mathrm{P}$ and $\mathrm{Ti}$ anomaly but no anomaly in $\mathrm{Zr}$. This may indicate that apatite may be a residual phase but no ilmenite. The ranges in normalized La abundances and rather constant $\mathrm{Yb}$ abundances are consistent with melting occurring in garnet stability field. Nephelinite and melilitite have similar and parallel trace and REE normalized patterns. Primitive mantle-normalized trace-element compositions of the nephelinite rocks display a typical OIB signature with an enrichment of strongly incompatible element contents $(\mathrm{Rb}, \mathrm{Ba}, \mathrm{Sr}, \mathrm{Th})$. An important characteristic of the trace element enrichment patterns of the nephelinite, melilitite and haüynophyre is that the LILEs $(\mathrm{Ba}, \mathrm{Th})$ are at about the same level or slightly lower than the La (Figures 8(a)-(c)). The depletions in $\mathrm{Cr}$ and $\mathrm{Ni}$ and enrichments in incompatible elements such as $\mathrm{Ba}, \mathrm{Sr}, \mathrm{Rb}, \mathrm{Zr}$ and $\mathrm{Nb}$ reflect olivine, pyroxene and spinel crystallization. Negative $\mathrm{K}$ and $\mathrm{Rb}$ anomalies accompanied by distinctive positive peaks of $\mathrm{Ba}$ and $\mathrm{Nb}$ are characteristic of basaltic rocks of anorogenic affinity of the Central European Volcanic Province [35]. The negative $\mathrm{K}$ and $\mathrm{Rb}$ anomalies accompanied by high and variable $\mathrm{K} / \mathrm{Rb}$ and $\mathrm{Zr} / \mathrm{Hf}$ ratios are typical of Bioko basaltic lavas and the Mount Cameroon

[36]. These trace element features are believed to result from melting of mantle sources initially slightly depleted with metasomatized by slab-derived, $\mathrm{H}_{2} \mathrm{O}$-rich phases segregating mobile from non mobile elements.

Geochemical characteristics observed on the nephelinite lavas are similar or identical of the Mount Cameroon lavas [37] [38] and [39]. The whole-rock atomic $\mathrm{Mg} /(\mathrm{Mg}+\mathrm{Fe})$ ratio is practically identical to those of the basaltic lavas of the Cameroon Hot Line. The mineral assemblage of nephelinite could result from the basaltic magma by the pneumatolytic processes (reaction 1 and 2) and metasomatic processes (reaction 3) in agreement of [40], [41] respectively by the reaction:

$\mathrm{CaAl}_{2} \mathrm{Si}_{2} \mathrm{O}_{8}+3 \mathrm{MgSiO}_{3}+2 \mathrm{NaCl}+\mathrm{H}_{2} \mathrm{O}=\mathrm{CaMgSi}_{2} \mathrm{O}_{6}+2 \mathrm{NaAlSiO}_{4}+\mathrm{Mg}_{2} \mathrm{SiO}_{4}+2 \mathrm{HCl}$

Anorthite + Enstatite $+\mathrm{Gaz}=$ Diopside + Nepheline + Olivine $+\mathrm{Gaz}$ 


$$
\begin{aligned}
& \mathrm{NaAlSi}_{3} \mathrm{O}_{8}+2 \mathrm{CaAl}_{2} \mathrm{Si}_{2} \mathrm{O}_{8}+2 \mathrm{MgSiO}_{3}+4 \mathrm{NaCl}+2 \mathrm{H}_{2} \mathrm{O}=2 \mathrm{CaMgSi}_{2} \mathrm{O}_{6}+5 \mathrm{NaAlSiO}_{4}+4 \mathrm{HCl} \\
& \text { Albite }+ \text { Anorthite }+ \text { Enstatite }+\mathrm{Gaz}=\text { Diopside }+ \text { Nepheline }+\mathrm{Gaz} \\
& \mathrm{NaAlSi}_{3} \mathrm{O}_{8}+\mathrm{CaAl}_{2} \mathrm{SiO}_{8}+\mathrm{Mg}_{2} \mathrm{SiO}_{4}+\mathrm{CaCO}_{3} \leftrightarrow \mathrm{NaAlSiO}_{4}+4\left(\mathrm{Ca}_{2} \mathrm{MgSi}_{2} \mathrm{O}_{7}+\mathrm{Ca}_{2} \mathrm{Al}_{2} \mathrm{SiO}_{7}\right)+12 \mathrm{CO}_{2} \\
& \text { Albite }+ \text { Anorthite }+ \text { Olivine }+ \text { Calcaire } \leftrightarrow \text { Nepheline }+ \text { Akermanite }+ \text { Gehlenite }+ \text { Gaz }
\end{aligned}
$$

\section{Discussion}

The nephelinite rocks described here are insignificant volume when compared to the basaltic rocks of Mont Cameroon, but probably abundant ultramafic rocks of the Cameroon Hot Line. The interstitial mineral reveals ambiguous textural position. Although forming the analcime, there is ample textural evidence that it has replaced zeolite. This suggests that it is late magmatic origin. The oxygen fugacity lower and silica activity evolution at the late-magmatic and metasomatic process of evolution in the nephelinite could be constrained from mineral equilibria of the Equations (1), (2) and (3). The nephelinites have high $\mathrm{Ba}$ and $\mathrm{Zr}$, and to a lesser degree high $\mathrm{K}$. The $\mathrm{Ba} / \mathrm{Zr}$ (1.4) and $\mathrm{Ba} / \mathrm{Nb}$ ratios are relatively high compared to some nephelinite $(\mathrm{Ba} / \mathrm{Zr}<1$, $\mathrm{Ba} / \mathrm{Nb}>3$ ) which suggests either amphibole was low in the mantle source [43], or that its contribution to the magma became diluted through the suspected mantle fractionation. Early nepheline in the nephelinites is sodic (ne ${ }_{72-77}$ ), and compositions suggest crystallization around $980^{\circ} \mathrm{C}$, based on experimental isotherms [44]. Estimates for crystallization temperatures from nepheline, however, may be minimum values due to potential exchanges of alkalis and aqueous vapour that reset them to lower kls and qtz and so apparently lower temperatures [45]. Clinopyroxenes in the nephelinite rocks cumulate and assemblages mostly show relatively lower $\mathrm{Al}^{\mathrm{IV}} / \mathrm{Al}^{\mathrm{VI}}$ ratios (0.9). Such ratios typically indicate low-pressure igneous crystallisation, rather than mantle and lower crust pressures [46]. Mass balance calculations performed with the olivine nephelinite give better fits $\left(1<\Sigma r^{2}<2\right)$.

\section{Conclusions}

Mineralogical, geochemical and trace elements are reported for the main nephelinite rocks on the Mount Etinde. The major and trace element composition of the host alkaline nephelinite suggest that fractional crystallization is not the only process involved in the petrogenesis of the nephelinitic lavas. The variation observed in their major and trace element position could be partly explained by fractional crystallization processes. The negative $\mathrm{P}$ anomaly may indicate that apatite may be a residual phase. These variations are consistent with crystallization processes dominated by removal of clinopyroxene \pm olivine and nepheline by low $\mathrm{aSiO}_{2}$ and low $\mathrm{fO}_{2}$. The residual minerals in their source are mainly amphibole and garnet, possibly subordinate orthopyroxene (Equation (1)). The large variations documented by the isotopic data suggest the presence of heterogeneous mantle involving HIMU and EMI component [8] (Fitton, 1984). The principal mantle components invoke geochemical characteristics of magma source hybride nature for the Mount Etinde rocks, which are responsible for the main isotopic signature $\left({ }^{87} \mathrm{Sr} /{ }^{86} \mathrm{Sr}\right.$ ranging between $0.7033-0.7030$ and ${ }^{143} \mathrm{Nd} /{ }^{144} \mathrm{Nd}$ ranging between 
$0.512793-0.512891)$. All these suggest that the nephelinites were derived from a depleted mantle source rather than a peridotite source.

The high $\mathrm{Zr} / \mathrm{Hf}(113$ - 163) observed in the nephelinite lavas indicated the assimilation of carbonatic liquid near the magma chamber after the pneumatolytic processes of the basaltic magmas origin in agreement by [40] Rittmann (1963). Equations (1), (2) and (3) show that nephelinites are derived from the basaltic lavas composition. The volatile rich nature of Etinde lavas and their high abundance in incompatible trace elements require the presence of metasomatized mantle and thus refertilization of the mantle source before the partial melting event. The formation of rare, late mineral phases in the nephelinites is also attributed to late-magmatic and/or subsolidus hydrothermal processes.

\section{Acknowledgements}

We are grateful to the following individuals who have greatly aided this study.

\section{References}

[1] Déruelle, B., Ngounouno, I. and Demaiffe, D. (2007) The "Cameroon HotLine" (CHL): A Unique Example of Active Alkaline Intraplatestructure in Both Oceanic and Continental Lithospheres. Comptes Rendus Geoscience, 339, 589-600. https://doi.org/10.1016/j.crte.2007.07.007

[2] Le Bas, M.J. (1987) Nephelinitite and Carbonatite. In: Fitton, J.G. and Upton, B.G.J., Eds., Alkaline Igneous Rocks, Geological Society, Special Publications, London, 30, 53-83. https://doi.org/10.1144/GSL.SP.1987.030.01.05

[3] Blancher, S. (2008) Le cœur alcalin du complexe du Messum, Namibie: Description pétrologique, interprétation de l'évolution minéralogique et relations roches sous-et sur-saturées en silice. Thèse de Doctorat Université Paris VI, Pierre et Marie Curie.

[4] Déruelle, B., N'ni, J. and Kambou, R. (1987) Mount Cameroon: An Active Volcano of the Cameroon Line. Journal of African Earth Sciences, 6, 197-214. https://doi.org/10.1016/0899-5362(87)90061-3

[5] Esch, E. (1901) Der Vulkan Etinde in Kamerun und seine Gesteine (I). Sitzungsberichte. Akad. Wiss. Berlin, 277-299.

[6] Gèze, B. (1941) Sur les massifs volcaniques du Cameroun OCcidental. C. R. Acad. Sci. Paris, 212, 498-500.

[7] Tilley, C.E. (1953) The néphelinite of Mont etinde, Cameroon, West Africa. Geological Magazine, 90, 145-151.

[8] Fitton, G. (1981) Strontian melilite in a nephelinite lava from Etinde, Cameroon.

[9] Mouafo, L. (1988) Contribution à l'étude géologique du Mont Etindé: Par exemple d'une série hyperalcaline fortement sous saturé. Thèse Doct 3 ème cycle, Université de Yaoundé, Yaounde, 157.

[10] Mouafo, L., Nkoumbou, C. and Tchoua, F. (1992) Données géomorphologiques et pétrologie sur le Mont Etindé, Géographie au Cameroun XI, 2, 90-100.

[11] Nkoumbou, C. (1990) Etude géochronologique des monts Rumpi: Un ensemble plutonique et volcanique de la "Ligne du Cameroun". 2. Données pétrologiques sur les néphénilites du Mont Etindé (Cameroun). Thèse Doct Université de Nancy I, 356. 
[12] Nkoumbou, C., Déruelle, B. and Velde, D. (1995) Petrology of Mount Etinde Nephelinite Series. Journal of Petrology, 36, 373-395. https://doi.org/10.1093/petrology/36.2.373

[13] Roffet, L. (2003) Géochimie du volcanisme du Mont Cameroun et du Mont Etindé. DEA, Université Joseph-Fourier, Grenoble, France.

[14] Etame, J., Gerard, M., Bilong, P. and Suh, C.E. (2009) Halloysite Neoformation during the Weathering of Nephelinitic Rocks under Humid Tropical Conditions at Mt Etinde, Cameroon. Geaderma, 154, 59-68.

[15] Etame, J., Suh, C.E., Gerard, M. and Bilong, P. (2012) Phillipsite Formation in Nephelinitic Rocks in Response to Hydrothermal Alteration at Mount Etinde, Cameroon. Chemie der Erde-Geochemistry, 72, 31-37.

[16] Tsafack, J.M., Wandji, J.P.F., Bardintzeff, D.G. and Nkouathio, A. (2007) Occurrence of a Sedimentary Basement under the Mount Cameroon Active Volcano (Cameroon Volcanic Line). 26th (ECGS: European center for Geodynamics and Seismology) Workshop, Active Volcanism and Continental Rifting (Accor-07), Luxembourg, 19-21 November 2007.

[17] Ngounouno, I. (2013) La pétrologie éruptive Moderne (Le Cameroun, l'Islande, les Andes). T2 Harmattan, 410 p.

[18] Pouchou, J.L. and Pichoir, F. (1991) Quantitative Analysis of Homogeneous or Stratified Microvolumes Applying the Model "PAP". In: Heinrich, K.F.J. and Newbury, D.E., Eds., Electron Probe Quantification, Plenum Press, New York, 31-75. https://doi.org/10.1007/978-1-4899-2617-3 4

[19] Andersen, D.J., Lindsley, D. and Davidson, P.M. (1993) QUILF: A PASCAL Program to Assess Equilibria among Fe-Mg-Mn-Ti Oxides, Pyroxenes, Olivine, and Quartz. Computers \& Geosciences, 19, 1333-1350. https://doi.org/10.1016/0098-3004(93)90033-2

[20] White, J.C, Ren, M. and Parker, D.F. (2005) Variation in Mineralogy, Temperature, and Oxygen Fugacity in a Suite of Strongly Peralkaline Lavas and Tuffs, Pantelleria, Italy. The Canadian Mineralogist, 43, 1331-1347. https://doi.org/10.2113/gscanmin.43.4.1331

[21] Ren, M., Onenda, P.A., Anthony, E.Y., White, J.C., Macdonald, R. and Bailey, D.K. (2006) Application of the QUILF Thermobarometer to the Peralkaline Trachytes and Pantellerites of the Eburu Volcanic Complex, East African Rift, Kenya. Lithos, 91, 109-124. https://doi.org/10.1016/j.lithos.2006.03.011

[22] Mbowou, I., Nguihdama, D., Yamgouot, F., Ntoumbe, M. and Ngounouno, I. (2013) TiBearing Aenigmatite from Djinga Tadorgal (Adamawa Plateau) and Sao Tomé (Cameroon Line) Phonolites: Geochemical Implications and Application of the QUILF Thermobarometer for the Crystallization Conditions. International Journal of Biology and Chemical Sciences, 7, 2601-2610.

[23] Fitton, J.G. and Dunlop, H.M. (1985) The Cameroon Line, West Africa, and Its Bearing on the Origin of Oceanic and Continental Alkali Basalt. Earth and Planetary Science Letters, 72, 23-38. https://doi.org/10.1016/0012-821X(85)90114-1

[24] Morimoto, N., Fabries, J., Ferguson, A.K., Ginzburg, I.V., Ross, M., Seifert, F.A. and Zussman, J. (1988) Nomenclature of Pyroxenes. American Mineralogist, 73, 1123-1133.

[25] Dawson, J.B., Smith, J.V. and Jones, A.P. (1985) A Comparative Study of Bulk Rock and Mineral Chemistry of Olivine Melilitites and Associated Rocks from East and South Africa. Neues Jahrbuchfür Mineralogie, Abhandlungen, 152, 143-175.

[26] Coleman, R.G. (1965) Eclogites and Eclogites: Their Differences and Similarities. Geological Society of America Bulletin, 76, 483-508. https://doi.org/10.1130/0016-7606(1965)76[483:EAETDA]2.0.CO;2

[27] Hoffer (2008) Fusion partielle d'un manteau métasomatisé par un liquide adakitique: Ap- 
proches géochimique et expérimentale de la genèse et de l'évolution des magmas de l'arrière arc équatorien. Thèse de l'Université Blaise Pascal, 334 p.

[28] Deer, W.A. and Abbot, D. (1965) Clinopyroxène of the Gabbro Cumulates of the Edvard Holm Complex, East Greenland. Mineralogical Magazine, 34, 177-193.

https://doi.org/10.1180/minmag.1965.034.268.14

[29] De Vries, R.C., Roy, R. and Osborn, E.F. (1955) Phase Equilibria in the Systeme $\mathrm{CaO}-\mathrm{TiO}_{2}$ $\mathrm{SiO}_{2}$. Journal of the American Ceramic Society, 38, 158-171. https://doi.org/10.1111/j.1151-2916.1955.tb14922.x

[30] Stormer J.C. (1973) Calcium Zoning in Olivine and Its Relationship to Silica Activity and Pressure. Geochimica et Cosmochimica Acta, 37, 1815-1821. https://doi.org/10.1016/0016-7037(73)90144-0

[31] Maurel, C. and Maurel, P. (1982) Etude expérimentale de la distribution de l'aluminium entre bain silicaté basique et spinelle chromifère. Implications pétrogénétiques: Teneur en chrome des spinelles. Bulletin Minéralogie, 105, 197-202.

[32] Sack, R.O. and Ghiorso, M.S. (1991) Chromian Spinels as Petrogenetic Indicators: Thermodynamics and Petrological Applications. American Mineralogist, 76, 827-847.

[33] Shannon, R., Iishi, K., Allik, T., Rossman, G.R. and Liebertz, J. (1992) Dielectric Constants of $\mathrm{BaO}$ and Melilites and Oxide Additivity Rule. European Journal of Mineralogy, 4, 12391249.

[34] Donaldson, C.H., Dawson, J.N., Kanaris-Sotiriou, R., Batchelor, R.A. and Walsh, J.N. (1987) The Silicate Lavas of Oldoinyo Lengai, Tanzania. Neues Jahrbuch für Mineralogie Abhandlungen, 156, 247-279.

[35] Lustrino, M. and Wilson, M. (2007) The Circum-Mediterrane an Anorogenic Cenozoic Igneous Province. Earth-Science Review, 81, 1-65.

[36] Yamgouot, F.N., Déruelle, B., Mbowou, G.I.B. and Ngounouno, I. (2015) Petrology of the Volcanic Rocks from Bioko Island ("Cameroon Hot Line”). International Journal of Geosciences, 6, 247-255. https://doi.org/10.4236/ijg.2015.63019

[37] Ngounouno, I., Déruelle, B., Montigny, R. and Demaiffe, D. (2006) Les camptonites du Mont Cameroun, Cameroun, Afrique. Comptes Rendus Géoscience, 338, 537-544. https://doi.org/10.1016/j.crte.2006.03.015

[38] Nguihdama, D., Chazot, G., Pierre, K., Bertrand, M.G.I., Ismaïla, N. (2014) Spinel-Bearing Lherzolite Xenoliths from Hosséré Garba (Likok, Adamawa-Cameroon): Mineral Compositions and Geothermobarometric Implications. International Journal of Geosciences, 5, 1435-1444.

[39] Wandji, J.P.F., Tsafack, J.M., Bardintzeff, D.G., Nkouathio, A., Kagou, D.H., Bellon, H. and Guillou, H. (2009) Xenoliths of Dunite, Wehrlites and Clinopyroxenites in the Basanite from Batoke Volcanic Cone (Mount Cameroon, Central Africa) Petrogenetic Implication. Mineralogy and Petrology, 96, 81-98. https://doi.org/10.1007/s00710-008-0040-3

[40] Harris, P.G. (1972) Geothermal Environment and Basalt Magma Type. Journal of Earth Science, 8, 275-281.

[41] Rittmann, A. (1963) Les volcans et leur activité. Edition MASSON et $\mathrm{C}^{\mathrm{IE}}, 461 \mathrm{p}$.

[42] Sun, S. and McDonough, W.F. (1989) Chemical and Isotopic Systematics of Oceanics Basalts: Implications for Mantle Composition and Processes. Geological Society, London, Special Publications, 42, 313-345.

[43] Chazot, G., Menzies, M.A. and Harte, B. (1996) Determination of Partition Coefficients between Apatite, Clinopyroxene, Amphibole and Melt in Natural Spinel Lherzolites from 
Yemen: Implications of Wet Meltingin the Lithospheric Mantle. Geochimica et Cosmochimica Acta, 60, 423-427. https://doi.org/10.1016/0016-7037(95)00412-2

[44] Hamilton, D.L. (1961) Nepheline as Crystallization Temperature Indicators. The Journal of Geology, 69, 321-329.

[45] Edgar, A.D. (1987) The Genesis of Alkaline Magmas with Emphasis on Their Source Regions: Inferences from Experimental Studies. Geological Society, London, Special Publications, 30, 29-52. https://doi.org/10.1144/gsl.sp.1987.030.01.04

[46] Simonetti, A., Goldstein, S.L., Schmidberger, S.S. and Viladkar, S.G. (1998) Geochemical and $\mathrm{Nd}, \mathrm{Pb}$, and $\mathrm{Sr}$ Isotope Data from Deccan Alkaline Complexes-Inferences for Mantle Sources and Plume-Lithosphere Interaction. Journal of Petrology, 39, 1847-1864.

https://doi.org/10.1093/petroj/39.11-12.1847

\section{Submit or recommend next manuscript to SCIRP and we will provide best service for you:}

Accepting pre-submission inquiries through Email, Facebook, LinkedIn, Twitter, etc. A wide selection of journals (inclusive of 9 subjects, more than 200 journals)

Providing 24-hour high-quality service

User-friendly online submission system

Fair and swift peer-review system

Efficient typesetting and proofreading procedure

Display of the result of downloads and visits, as well as the number of cited articles

Maximum dissemination of your research work

Submit your manuscript at: http://papersubmission.scirp.org/

Or contact ijg@scirp.org 